\title{
Pragmatic Speech in Electronic Media Advertisement
}

\author{
Riris Tiani $^{1 *}$, Astri A.Allien ${ }^{2}$ \\ tiani.riris@gmail.com \\ Department of Indonesian Literature, Faculty of Humanities, Diponegoro University ${ }^{1}$, Department of \\ English, Faculty of Humanities, Diponegoro University ${ }^{2}$ \\ J1. Prof. Soedarto, Tembalang, Semarang, 50275, Indonesia
}

\begin{abstract}
This research aims to examine the speech strategy found in media advertisement. The speech applied is using pragmatic theory. Method used is qualitative descriptive method. The data collecting uses listening note taking method. The data collected will be classified then continued by descripting the speech's type and function. Advertisement is one of media promotion for a product and has an sigificant rule in increasing the production income. A product or service can be introduced to public by advertisement, so that everyone will be aware of the offered product or service. In this research analysis, there are many types of speech found in some advertisements. The speech made to grab people's interest by inserting attractive sentences. The promotion strategy in advertisement mostly are using locuitonary, illocution and perlocutionary act.
\end{abstract}

Keywords: speech; pragmatic; advertisement; media

\section{Introduction}

We all know that language is one of communication tools used by people. Language has informative, expressive, directive esthetic and phatic function [1]. Informative function can be described as a information carrier. Pragmatic Speech in Electronic Media AdvertisementConsidered as the main function of the language itself. In written KBBI, language is a system of arbitratory sound symbols, which are used by members of a community to work together, interact, and identify themselves. Sansoso said that the definition of language is a sound produced from human speech that is done unconsciously to form a pattern of language that is following the dialect of each human character itself. Language has an important role in human life, with the existence of language that makes all humans can communicate well to just exchange ideas or experiences with each other. In communication, there are two types of forms namely direct and indirect communication and oral and written communication. The language itself will later function to lead to a mutual understanding between communicators and communicants or between readers and writers. Language is an absolute thing that is used in communication and certainly is needed by humans.

Communication and language can lead to a speech act that functions as a form of expression of something. Speech action itself is found in one study in pragmatics. Pragmatics as a study of the meaning conveyed by speakers (or authors) and interpreted by listeners (or readers) or pragmatics itself is the study of the intent of speakers [2]. in pragmatics involves an interpretation of what is meant by someone in a context and how that context can influence what is said. Pragmatics is also a study of how to have more meaning conveyed than what is spoken. 
Yule argued that the sign of speech act can be an apology, complain, praise, promise or request. Speech act is divided into three: locutionary act, ilocuitonary act and perlocutionary act. Locutionary act is an act of saying something. Locutionary is an act to say a series of sentences which meaning is same as what is said. Locutionary acts has several forms, such as, declarative, imperative and interogative.

Ilocuitionary act is a speech an act to deliver or inform something and an act to make something is done. The basic Ilocutionary, which is usually called the act of doing something, is a speech that its existence has another meaning from the speaker. The meaning is implicit and make the speaker wants something is done. The third act is perlocutionary which aims to give the hearer a certain effect or the act of affecting [2]. All those three acts mentioned above are applied to daily conversation and can be found inmedia advertisement.

Advertisement is one of media to promote a company or products we are familiar with. Advertisement is a media to promote a product or service. Visual advertisement is more effective to attract people's interest and make them buy the product being advertised. The advertisement is not only visually colorful, but there are message that becomes the tag line. The verbal message in advertisement is the branding image of the advertisement.

Speech act found in advertisement has different strategy. That strategy can be reflected on verbal message in the advertisement. The verbal message inserted has different function. The speech's function is influenced by the speech act used. In this research, the writer will described the speech act of advertisement in media, to parse the speech strategy applied to advertise.

\section{Research Method}

This reseach is using desriptive qualitative method. The data source applied in this research is advertisements donwloaded online with some products offered. The writer intends to analyse the advertisement that have locutionary, ilocutionary and perlocutionary act. The method of collecting data used by the writer is listening and note taking method. The data noted by the writer is the speech delivered by the speaker in the advertisement video. Then, the data will be selected based on locutionary, ilocutionary and perlocutionary act and will be analysed. Finally, the conclusion will be made.

\section{Result and Discussion}

Speech act is divided into three type. Those are: locutionary, ilocutionary and perlocutionary act. Locutionary act is an act to say or inform something. Ilocutionary act is a speech act which its existence contains implicit meaning that can make the hearer does something. Perlocutionary act is an act that has a certain effect to the hearer. The analysis speech acts found in the electronic media advertisement will be explained below:

\subsection{Zalora Advertisement}


In the 30 seconds long Zalora advertisement shows a conversation yet with a naration delivered by the narator. In the beginning of the advertisement shows 3 female models who are busy selecting some clothing. In this scene, the narator says "Looking for something to wear for lebaran? Discover it on Zalora" followed by two male models appeared. Then it displays the models wearing the chosen outfit. Reflecting the naration at the beginning of the advertisement, the outfit wore are lebaran themed, such as gamis, skirt, long sleeved top, sweater, shirt, and the other lebaran themed clothings. In this scene, the narator continues by saying "Now $80 \%$ off for your various original brands with 30 days restitution". At the end of the advertisement there is a text "ALWAYS APPEAR FRESH", then the logo Zalora is displayed. In the closing scene, the narator says "always appear fresh only on Zalora".

According to the description above, we can see that there are three speech acts said by the narator, such as: "Looking for something to wear for lebaran? Discover it on Zalora", "Now $80 \%$ off for your various original brands with 30 days restitution", and "Always appear fresh only on Zalora". The first speech, "Looking for something to wear for lebaran? Discover it on Zalora", is a ilocutionary directive act. Ilocutionary act is an act to make the hearer does something, and direvtive is a imperative sentence to order the hearer to do something. In this sentence, the narator indirectly ask the hearer, who have trouble selecting the outfit for lebaran, to buy their cloyhing on Zalora only. Since it is ramadhan, clothing for lebaran is something hunted by people. So the speaker wishes that the hearer will buy the clothing at Zalora. Next is the sentence "Now $80 \%$ off for your various original brands with 30 days restitution" is locutionary representative act. Locutionary is an informative and representative speech act. In that sentence, the speaker gives the information about the free 30 days restitution if there should be any issue with the product. The information is is true and can be checked on the website. Lastly, the sentence "always appear fresh only on Zalora" is a expressive ilocutionary. In that speech, the speaker indirectly asks the hearer to buy their clothing on Zalora if they want to look fresh.

\subsection{Mylanta Advertisement}

Mylanta advertisement is a 31 seconds long advertisement. This advertisement shows a family who are breaking the fast. The family consists of grandmother, father, mother and children. In the beginning of the video, the grandmother says "breakinf the fast" with the sign of bedug sound which is signaling the time. Then, one of the children whines and says "Ouch, my stomach ulcer". Then, the narator says "When stomach ulcer attacks, go get mylanta" with the children in pain as the background while drinking Mylanta and the narator continues "Mylanta with quick action formula reduce your pain instantly", with an animation that shows how Mylanta works in the peptic. In the closing scene, the narator says "Mylanta helps reducing your stomach ulcer pain and keeps the silaturahmi going well."

As can be seen above, there are speech uttered by narator or the models. In the first utterance "breaking the fast" said by the grandmother is an directive ilocutionary act. Ilocutionary act is imperative. The grandmother announces "breaking the fast" when there is bedug sound to make the other characters doing so. This is an imperative act to make other people doing like what has been said. Then there is "Ouch, my stomach ulcer" utterance said by the child. This utterance is an directive ilocutionary speech and the child wants something to be done to his pain. Then the grandmother gives him the Mylanta to reduce the pain. In this scene, the naration spoken by the narator is "When your ulcer is hurt, take Mylanta immediately", that utterance is an directive ilocutionary act because that naration gives an advice to take Mylanta immediately. In the closing scene, "Mylanta helps reducing your stomach ulcer pain and keeps the silaturahmi going 
well." This is a representative locutionary act where there is an information about the effect that Mylanta has which helps reduce the pain and keep the silaturahmi going well. The truth about the information is when the family gathers without no one in pain.

\subsection{Listerin Advertisement}

Listerin Advertisement is 32 seconds long with Arie Untung's family as the main characters. In the opening, there is a naration "Listerin makes your mouth extra clean while 12 hours fasting. Brushing your teeth only is not enough. Use Listerin to reduce the $99,9 \%$ bacteries for fresh breath" with Arie Untung's family using the product, as the main background. Then continued by "makes Arie's family feel confident in doing silaturahmi even to strangers" naration and shows Arie's family greets the people around them without being afraid of bad breath. It is ended while showing the product.

In the first utterance delivered by the narator, "Listerin makes your mouth extra clean while 12 hours fasting" is a expressive ilocutionary act where the speaker asks the hearer to use Listerin because Listerin can make your breath odorless eventhough you have to fast for 12 hours. Ilocutionary is an act when the speaker needs the hearer to do something and expressive is a speech that depicted a condition. This utterance is intriguing the hearer to buy the offered product. Then, there is "Brushing your teeth only is not enough. Use Listerin to reduce the $99,9 \%$ bacteries for fresh breath" utterance which is a directive ilocutionary. Ilocutionary is a speech that provides information to the hearer, meanwhile directive is an utterance that requires the hearer to do something. In the utterance, the narator tells that brushing your teeth only is not enough to make your mouth feels fresh and odorless. The utterance can be classified as an imperative sentence for the hearer to buy the product. Then continued by "makes Arie's family feel confident in doing silaturahmi even to strangers" which is a representative locutionary. Locutionary is an informative act and representative is the truth. The information showed by Arie untung's family interacting with strangers confidently.

\subsection{Split Candy Advertisement}

This advertisement is 30 seconds long with 3 main characters; a older brother, younger sister and their mother. In the opening we can see the older brother is enjoying the candy alone and the younger sister appears while saying "I want some". When her brother is unresponsive, she is getting upset and calls her brother stingy. Their mother comes and asks what is happening. The younger sister says "I want that Split candy" and the brother is responding "I finished all of them because of the fresh lemon flavor". The mother tells the younger sister to buy the candy. The older brother asks for some candies but she refuses to share them by saying "I will not give you, Split candy is good".

In the conversation above, there is "I finished all of them because of the fresh lemon flavor" utterance which is an expressive locutionary act. Locutionary is an informative act and expressive is utterance that is expressing a certain condition. The older brother does not want to share his candies because they are so refreshing and finishes them all by himself. The older brother gives the hearer that the candies he enjoyed are refreshing and has lemony taste. It can be seen by the older brother's expression. Just before the video ends, the younger sister brings her own candies, the brother wants his share but she refuses to give some. "I will not give you, Split candy is good" utterance by the younger sister shows information that the candies are too good to share.

\subsection{Kiko Advertisement}


The advertisement is 30 seconds long with abundant children characters and two adults as parents. The situation is crowded. In the beginning of the video, there children playing in the yard cheerfully. Then, the mothers takes some Kiko products out of the freezer then brings them to the yard where the children play while saying "Kiko Tropikal". The children are rushing towards the mother and choose the wanted flavor. They are saying "wow it is bigger," "it's good, right?" "the bigger the more flavorful" while enjoying the products. In the end of the video, they say together " 1000 is more fun. Kiko Tropical is refreshing. The bigger the more flavorful."

There is an utterance "wow it is bigger" said by a kid as a respond. That utterance is a representatif locutionary act. Locutionary act is giving information to the hearer, meanwhile representative is utterance based on the actual condition. Information given by the the kid is the size of Kiko is getting bigger. The size of Kiko Tropical is indeed way bigger which is matched with the utterance saying that the price is Rp 1000,-, more expensive than the old variant. The final utterance " 1000 is more fun Kiko Tropical is refreshing. The bigger the more flavorful," is a representative ilocutionary. Ilocutionary is an utterance to influence the hearer to do something and representative is a utterance matched with the actual condition. The utterance " 1000 is more fun" and "the bigger the more flavorful" said to attract the hearer and make them try the product. The speaker wants the hearer to enjoy the flavor and it can be seen by the expression they make when enjoying the bigger Kiko.

\section{Conclusion}

Advertisement is one of media to promote a product or service and has a significant role in increasing the production income. By advertisement, a product of service can be introduced to the public, so everyone will familiar with the product offered. In the analysis there are various speech acts found in those advertisements. Those speech acts are made to make the advertisements are more interesting. The promotion strategy of advertisement is tend to use locutionary, ilocutionary and perlocutionary act.

\section{References}

[1] Levinson, Stephen C. Pragmatics. Cambridge: Press Syndicate of the University of Cambridge (1983).

[2] Yule, George. Pragmatik. Yogyakarta: Pustaka Pelajar (2014). 